SOI: $1.1 /$ TAS DOI: $10.15863 /$ TAS

International Scientific Journal Theoretical \& Applied Science
p-ISSN: 2308-4944 (print) e-ISSN: 2409-0085 (online)

Year: 2017 Issue: $05 \quad$ Volume: 49

Published: $27.05 .2017 \quad$ http://T-Science.org

SECTION 25. Technologies of materials for the light and textile industry.
Olga Nikolaevna Baranova candidate of technical Sciences, a College lecturer of Russian state University named after Kosygin, Kosygin University bon-20@bk.ru

Viktor Yureivich Mishakov candidate of technical Sciences, associate Professor Russian state University after A. N. Kosygina

Ludmila Ivanovna Zolina candidate of chemical Sciences, associate Professor Russian state University after A. N. Kosygina

\title{
THE ANALYSIS OF CHEMICAL ANTISEPTIC TANKS FOR THE PURPOSE OF THE CHOICE OF OPTIMUM MEDICINE FOR MODIFYING LINEN RANGE COTTON MATERIALS
}

Abstract: The comparative analysis of a wide range of the modern medicines giving antiseptic properties to cotton fabrics is carried out. Primary benefits of silver nanoparticles, such as ecological safety, non-volatility and indifference in relation to resident microflora of the person are provided. Results of cotton fabrics processing by silver hydrosols with the subsequent fixing of a tanidama are shown. It is fixed that the developed technology allows to give to fabrics resistant antiseptic the effect which is remaining after several wet thermal treatments.

Key words: antiseptic activity, colloidal silver, stabilizers, tanida, biocidal, bactericidal, bakteriostatic properties of samples.

Language: Russian

Citation: Baranova ON, Mishakov VY, Zolina LI (2017) THE ANALYSIS OF CHEMICAL ANTISEPTIC TANKS FOR THE PURPOSE OF THE CHOICE OF OPTIMUM MEDICINE FOR MODIFYING LINEN RANGE COTTON MATERIALS. ISJ Theoretical \& Applied Science, 05 (49): 151-160.

Soi: http://s-o-i.org/1.1/TAS-05-49-23 Doi: crostef https://dx.doi.org/10.15863/TAS.2017.05.49.23

\section{АНАЛИЗ ХИМИЧЕСКИХ АНТИСЕПТИКОВ С ЦЕЛЬЮ ВЫБОРА ОПТИМАЛЬНОГО ПРЕПАРАТА ДЛЯ МОДИФИЦИРОВАНИЯ ХЛОПЧАТОБУМАЖНЫХ МАТЕРИАЛОВ БЕЛЬЕВОГО АССОРТИМЕНТА}

Аннотация: Проведен сравнительный анализ широкого спектра современных препаратов, придающих антисептические свойства хлопчатобумажным тканям. Представлены основные преимущества наночастии серебра, такие как экологическая безопасность, нелетучесть и индифферентность по отношению к резидентной микрофлоре человека. Показаны результаты обработки хлопчатобумажных тканей гидрозолями серебра с последующим закреплением танидами. Установлено, что разработанная технология позволяет придать тканям стойкий антисептической эффект, сохраняюшийся после нескольких влажно-тепловых обработок.

Ключевые слова: относительная деформачия, пластическая (остаточная) деформация, упругая деформация пакеты одежды, бикомпонентные волокна. теплофизические свойства, модели структуры, пакеты материала.

\section{Introduction}

Защита людей от воздействия патогенной микрофлоры окружающей среды является важнейшей задачей современной экологической политики государства, решение которой позволит повысить качество жизни человека. Опасность микрофлоры заключается в том, что она содержит не только общеизвестные, патогенные и условно-патогенные бактерии, грибки и вирусы, но и их мутированные формы. В связи, с чем требуется разработка разнообразных мер профилактики, в частности создание новых эффективно действующих средств на патогенную транзиторную микрофлору и в то же время щадящих резидентную (или постоянную) флору человека.

Одной из профилактических мер снижения риска возникновения инфекционного процесса является изготовление изделий текстильной и лёгкой промышленности из текстильных полотен с антисептическими свойствами, которыми обладают исходные 
волокна, либо которые придаются им в процессе обработки [1].

В задачи исследования входил анализ биологически активных реагентов, применяемых для модифицирования текстильных материалов, а также определение оптимального состава препарата на основе наночастиц серебра для хлопчатобумажных материалов бельевого ассортимента.

\section{Materials and Methods}

Анализ литературных данных показал, что естественные ингибирующие свойства полотен, выработанных из натуральных волокон, таких как целлюлоза (лен), шёлк и шерсть, слабо проявляются в агрессивной патогенной среде. Их можно использовать только в профилактических целях при защите от условно-патогенной флоры [2].

Весь спектр химических антисептиков с микробиологической точки зрения можно разделить на следующие группы:

a) биоциды - для ликвидации бактерий и грибков;

б) бактерициды - для ликвидации бактерий;

в) бактериостатики - для нейтрализации бактерий;

г) фунгициды - против действия грибковой плесени $[3,4]$.

С химической точки зрения систематизация этих веществ, как органического, так и неорганического происхождения может быть представлена следующим образом [3, 4]:

1. Углеводороды и их, галоген - и нитропроизводные.

2. Спирты, фенолы и их производные.
3. Амины, соли аминов, четвертичные аммониевые соединения и их производные.

4. Гетероциклические соединения.

5. Неорганические соединения.

Ниже приведены свойства наиболее распространенных химических антисептиков каждой группы.

1. Ассортимент галоген- $\boldsymbol{u}$ нитропроизводных углеводородов, используемых в качестве биоцидов достаточно широк и разнообразен. Они могут использоваться не только как контактные биоциды для защиты натуральной кожи, например, бромтан $\mathrm{C}_{5} \mathrm{H}_{7} \mathrm{Br}_{2} \mathrm{Cl}_{3}$, но и как фумиганты (пестициды). Однако, ткани, обработанные биоцидами этого класса, не сохраняют антисептических свойств после влажных обработок. Поэтому применение галоген- и нитропроизводных углеводородов не эффективно для модифицирования текстильных материалов [5].

2.Спирты, феноль и их производные обладают широким спектром биоцидного действия. Биоцидная активность фенолов значительно выше, чем спиртов. Такие соединения, как 2-окси-дифенил применяют при жировании натуральных кож, $n$-нитрофенол - для защиты натуральной кожи [3]. Пентахлорфенол получил широкое распространение для защиты целлюлозных материалов при хранении. Но так как этот реагент легко растворим в воде, то легко удаляется при стирках и поэтому не рекомендуется для модификации текстильных материалов.

Одним из ароматического производного фенола для модификации текстильных материалов является гексахлорофен:<smiles>Oc1c(Cl)cc(Cl)c(Cl)c1Cc1c(Cl)c(Cl)cc(Cl)c1Cl</smiles>

Продукт взаимодействия гексахлорофена с привитым сополимером целлюлозы достаточно устойчив к гидролизу, поэтому текстильные материалы из этого волокна, выдерживают без заметного снижения антимикробных свойств до 30 стирок. Гексахлорофен проявляет высокую активность в отношении грамположительных бактерий и обладает фунгицидным действием, однако он не воздействует на грамотрицательной бактерии. [6]. К тому же гексахлорофен в США и Канаде включен в Список опасных веществ. [7]. Поэтому этот реагент имеет ограниченную область применения при модифицировании текстильных материалов.

Известным антибактериальным агентом, который действует на грамположительную и на грамотрицательную флору, а также на грибковые микроорганизмы является триклозан (2,4,4трихлор-2-гидроксидифениловый эфир): 


\begin{tabular}{|c|c|c|c|c|c|c|}
\hline Impact Factor: & $\begin{array}{l}\text { ISRA (India) } \\
\text { ISI (Dubai, UAE } \\
\text { GIF (Australia) } \\
\text { JIF }\end{array}$ & $\begin{array}{l}=1.344 \\
=0.829 \\
=0.564 \\
=1.500\end{array}$ & $\begin{array}{l}\text { SIS (USA) } \\
\text { PИНЦ (Russia) } \\
\text { ESJI (KZ) } \\
\text { SJIF (Morocco) }\end{array}$ & $\begin{array}{l}=0.912 \\
=0.234 \\
=3.860 \\
=2.031\end{array}$ & $\begin{array}{l}\text { ICV (Poland) } \\
\text { PIF (India) } \\
\text { IBI (India) }\end{array}$ & $\begin{array}{l}=6.630 \\
=1.940 \\
=4.260\end{array}$ \\
\hline
\end{tabular}<smiles>Oc1cc(Cl)ccc1Oc1ccc(Cl)cc1Cl</smiles>

Триклозан, начиная с 70-х годов XX века, активно применяется в моющих и чистящих средствах, средствах личной гигиены, таких как мыло, зубная паста, дезодоранты. Триклозан входит в состав антимикробного препарата Санитайзед (Коммерческая форма продукта «Sanitized» (производитель «Evonik Goldschmidt», Германия). Помимо него эта смесь включает пропиленгликоль - 55\% массовых долей и полиоксиэтилен-25-глицерилтриолеат - $35 \%$ массовых долей. В рабочих концентрациях триклозан действует как биоцид, при более низких концентрациях обладает бактериостатическим действием, препятствующим синтезу жирных кислот, необходимых для создания и воспроизведения клеточных мембран. Триклозан разрушает фермент ENR, необходимый бактериям для синтеза клеточных мембран. У человека фермент ENR отсутствует, поэтому считается, что триклозан безвреден для людей. Однако в последние годы, учитывая результаты опыта применения, происходит отказ от этого компонента в виду того, что пропиленгликоль, входящий в состав триклозана, вызывает аллергические реакщии. Начиная с 2000 года в ряде исследований были обнаружены микроорганизмы, устойчивые к триклозану. Появляется доказательства того, что при использовании триклозана развиваются бактерии, устойчивые к лекарственным антибиотикам и антибактериальным препаратам. Исследования показывают, что использование триклозана обеспечивает благоприятные условия для появления антимикробных лекарственноустойчивых бактерий, даже при низких концентрациях во многих продуктах и косметике [8].

Хлоргексидин, представляющий собой 1,6-ди- $\mathrm{N}_{1}, \quad \mathrm{~N}_{1}{ }^{\prime}$-n-хлор-

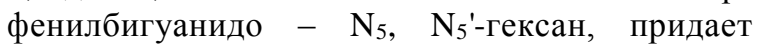
бактериальную активность ткани при концентрации $0,025 \%$ массовых долей. Этот препарат, проявляет активность в отношении широкого спектра и грамположительных и грамотрицательных бактерий [9]. Однако он легко удаляется при мокрых обработках, поэтому применение этого препарата для модификации текстильных материалов неэффективно.

Наряду с гексахлорофеном и хлоргексидином практическое применение находит пентахлорофен, но этот препарат и его водорастворимые соли обладают высокой токсичностью и неприятным запахом, что ограничивает его применение [10].

Широким спектром биоцидного действия и относительно низкой токсичностью обладает соединение нитрофуранового ряда - фурагин 1 [b-(5 нитрофурил-2-акрилиденамино) гидантоин]:

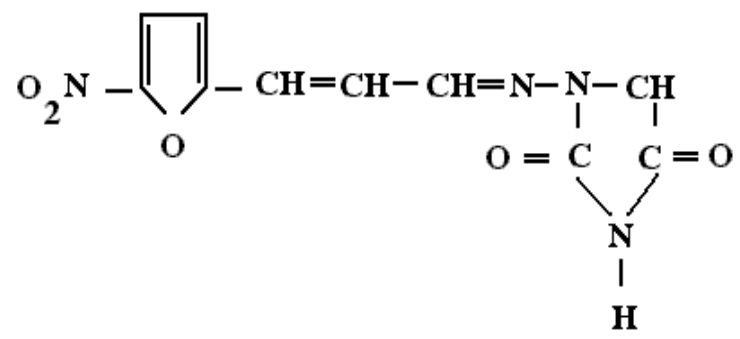

В молекуле фурагина содержится имидный водород, способный замещаться металлами. Такие соединения фурагина мало растворимы в воде, что позволяет придавать текстильным полотнам устойчивые при эксплуатации антимикробные свойства $[10-13]$. Фурагин активен в отношении грамположительных (стафилококки, стрептококки), грамотрицательных микроорганизмов (кишечная палочка) за исключением синегнойной палочки [11], помимо болезнетворной флоры активно подавляет резидентную флору. Поэтому область применения этого препарата при модифицировании текстильных материалов ограничена.

Соединения, содержащие азот в молекулах углеводородов с характерной структурой: 


\begin{tabular}{|c|c|c|c|c|c|c|}
\hline Impact Factor: & $\begin{array}{l}\text { ISRA (India) } \\
\text { ISI (Dubai, UAE } \\
\text { GIF (Australia) } \\
\text { JIF }\end{array}$ & $\begin{array}{l}=1.344 \\
=0.829 \\
=0.564 \\
=1.500\end{array}$ & $\begin{array}{l}\text { SIS (USA) } \\
\text { PИНЦ (Russia) } \\
\text { ESJI (KZ) } \\
\text { SJIF (Morocco) }\end{array}$ & $\begin{array}{l}=0.912 \\
=0.234 \\
=3.860 \\
=\mathbf{2 . 0 3 1}\end{array}$ & $\begin{array}{l}\text { ICV (Poland) } \\
\text { PIF (India) } \\
\text { IBI (India) }\end{array}$ & $\begin{array}{l}=6.630 \\
=1.940 \\
=4.260\end{array}$ \\
\hline
\end{tabular}

$\begin{array}{cccc}\mathrm{A}-\mathrm{NH}-\mathrm{C}-\mathrm{NH}-\mathrm{C}-\mathrm{NH}-\mathrm{R}-\mathrm{NH}-\mathrm{C}-\mathrm{NH}-\mathrm{C}-\mathrm{NH}-\mathrm{B} \\ \| & \| & \| & \| \\ \mathrm{NH} & \mathrm{NH} & \mathrm{NH} & \mathrm{NH}\end{array}$

где А и В - ароматические ядра (одинаковые или различные), с галогенными, гидроксильными или другими заместителями, a $\mathrm{R}$ - углеводородная метиленовая цепочка или диалкоксифенильная группа, которая обуславливает проявление антибактериальных (бактерицидных) и антифунгальных (фунгицидных) свойств, достаточно широко используются для модифицирования текстильных материалов. Однако для синтеза подобных соединений необходимы специальные установки, что связано с дополнительными финансовыми затратами [14].

Салициланилид или анилид салициловой кислоты (ширлан; салнид; хемоцид):

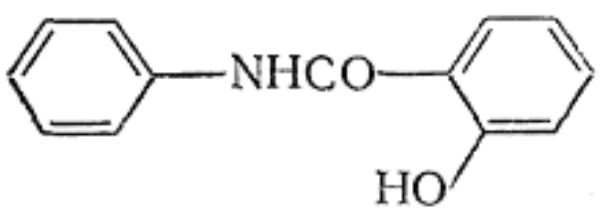

используется в производстве биостойкой упаковочной бумаги и картона, для защиты текстильных материалов. Салициланилид являясь фунгицидом, воздействует на ограниченный спектр микроорганизмов - грибы. Применение такого реагента для получения антисептических текстильных материалов является неэффективным [15].
3. Из группы аминов, солей аминов, четвертичных аммониевых соединений наиболее часто применяется алкилдиметилбензиламмония хлорид (Катамин $A Б)$, который представляет собой катионное поверхностно-активное вещество с комплексом всех биоцидных свойств $[11,12,16]$ :

$$
\left[\begin{array}{c}
\mathrm{CH}_{3} \\
\mid \\
\mathrm{CH}_{3}-\left(\mathrm{CH}_{2}\right)_{2 n+1}-\mathrm{N}^{+}-\mathrm{CH}_{2} \mathrm{C}_{6} \mathrm{H}_{5} \\
\mathrm{C} \mathrm{CH}_{3}
\end{array}\right]
$$

Катамин АБ используется для дезинфекиии тканей, в медиичнских изелях (для обработки рук хирурга, операционного поля и раневых поверхностей, а также дезинфекции хирургических инструментов, предметов ухода за больными и помещений) $[11,17]$. Но он относится к 3-му классу опасности умеренно onacнblx веществ, в связи, с этим применение Катамина АБ для модификации текстильных материалов непосредственно и длительно контактирующих с кожей человека имеет ограниченный характер [16].

Новые красители (гетарилазо-соединения), производные пиразолона, где диазокомпоненты представлены поли-функциональными ароматическими аминами, применяют для выкраски музейных тканей. Высокое фунгицидное действие отмечено у соединений, где в диазокомпоненте отсутствует сульфогруппа, а нитрогруппа находится в параположении (а не в орто-) относительно -ОН группы. При замене нитрогруппы в азокомпоненте на метоксигруппу происходит ослабление фунгицидной активности (ФА). Наличие пиразольного цикла в структуре диазокомпоненты обеспечивает высокую ФА. Замена пиразольного цикла на барбитуровый фрагмент снижает подавляющее действие. Почти все азосоединения, содержащие ОН-группы в орто-, орто'-положениях к азогруппе, оказывали подавляющее действие на тест-культуры, что связано со способностью этих красителей к хелатообразованию [18].

4. Наиболее известным гетероциклическим соединением, является нитрофурилакролеин, применяемый при получении синтетического водонерастворимого поливинилспиртового волокна желтого цвета «летилана», обладающего широким спектром биоцидного действия.

К гетероциклическим соединениям относятся соли четвертичных аммониевых 


\begin{tabular}{|c|c|c|c|c|c|c|}
\hline Impact Factor: & $\begin{array}{l}\text { ISRA (India) } \\
\text { ISI (Dubai, UAE } \\
\text { GIF (Australia) } \\
\text { JIF }\end{array}$ & $\begin{array}{l}=1.344 \\
=0.829 \\
=0.564 \\
=1.500\end{array}$ & $\begin{array}{l}\text { SIS (USA) } \\
\text { PИНЦ (Russia) } \\
\text { ESJI (KZ) } \\
\text { SJIF (Morocco) }\end{array}$ & $\begin{array}{l}=0.912 \\
=0.234 \\
=3.860 \\
=\mathbf{2 . 0 3 1}\end{array}$ & $\begin{array}{l}\text { ICV (Poland) } \\
\text { PIF (India) } \\
\text { IBI (India) }\end{array}$ & $\begin{array}{l}=6.630 \\
=1.940 \\
=4.260\end{array}$ \\
\hline
\end{tabular}

оснований, производные фенола, нитрофураны, антибиотики, антимикробные красители и другие [19-22].

- цефалоспорин

- тетрациклин

и др.

Клинические исследования анти-биотиков показали, что к ним чувствительна грамположительная и грамотрицательная микрофлора, в том числе кишечная группа бактерий, протей, синегнойная палочка $[13,23]$. Но применение антибиотиков угнетает работу
Для придания биоцидных свойств текстильным материалам используют антибиотики [12, 13, 17, 23], такие как:<smiles>CN(C)C1=C2C=C3C(=C(O)C(O)(C=C1C(N)=O)C2(C)O)C(O)=C(O)C3(C)O</smiles>

- бриллиантовый зеленый<smiles>CCC(C)[N+](C)(CC)C(=O)C(=O)O</smiles>

- метиленовый синий<smiles></smiles>

- этакридина лактат<smiles>Nc1ccc2c(N)c3cc(OCC(C=O)C(=O)O)ccc3nc2c1</smiles>

Они обладают невысокой токсичностью и избирательным действием к микроорганизмам $[12,13]$. Особенно чувствительны к анилиновым красителям грамположительные бактерии - иммунной системы, поэтому применение их в модификации тканей ограничено.

Антимикробные анилиновые красители также применяются в качестве биоцидов для модифицирования тканей, например, такие как $[10$ - 12, 14, 24]: 
антимикробное действие красителей резко снижается [17].

5. Ингибирующие свойства неорганических биоцидов связаны, главным образом, с взаимодействием катионов металлов $\left(\mathrm{Cd}^{2+}\right.$, $\left.\mathrm{Pb},{ }^{2+} \mathrm{Ag},{ }^{+} \mathrm{Cu}^{2+}\right)$ и некоторых анионов $\left(\mathrm{SO}_{4}{ }^{2-}, \mathrm{C} 0_{4}{ }^{2-}\right.$, $\left.\mathrm{C1}^{-} \mathrm{F}^{-}, \mathrm{B}^{-}\right)$с различными функциональными группами пептидогликанов, что приводит к нарушению организации структуры белковой молекулы, денатурации белков, нарушению функции дыхания и гибели клетки.

По интенсивности биоцидного действия ионов металлов на бактерии и грибы их можно разделить на три группы:

наиболее активные - серебро, ртуть, медь;

средней активности - кадмий, хром, свинец, кобальт, цинк;

наименее активные - железо, кальций [3].

Широкое применение для придания антимикробных свойств текстильным материалам получили соединения меди, благодаря невысокой стоимости, незначительной токсичности и достаточно высокой биологической активности. Материалы, обработанные солями меди, проявляют устойчивый антимикробный эффект, сохраняющийся после многократных стирок, обладают вирулицидным (антивирусным) действием $[12,24]$.

Купроцин (8-оксихинолят меди) с 1947г. занимает ведущее положение среди фунгицидов для модификации текстильных материалов и защиты красок, древесины, бумаги, пластмасс. Его применяют для обработки тары, помещений, оборудования [3]. Так как купроцин является только фунгицицом, применение для модифицирования тканей бельевого назначения ограничено.

Среди солей меди и органических кислот лучшими биоцидами являются стеарат меди (медное мыло) и нафтенат меди. Эти препараты не вымываются при стирке. Недостатком их является окрашивание ткани в сине-зеленый цвет $и$ снижение стойкости целлюлозных волокон $к$ действию солнечного света. 8Оксихинолят меди - также эффективный фунгицид и бактерицид. Однако он окрашивает ткани в желто-зеленый цвет, при этом на свету окраска темнеет до коричневого цвета [24].

Хороший антимикробный эффект достигается при обработке волокнистых материалов соединениями производными олова с общей формулой $\mathrm{R}_{3} \mathrm{SnX}$ или $\left[\mathrm{R}_{3} \mathrm{Sn}\right]_{2} \mathrm{O}$, (олово) где $(\mathrm{R}$ - алкил, циклоалкил, фенил и др., $\mathrm{X}$ - остаток любой кислоты), которые характеризуются значительной биоцидной активностью. Однако они обладают высокой токсичностью [12, 13]. Хотя за рубежом и используются соли фенилртути: ацетат, олеат, стеарат и другие для модификации текстильных материалов, применение их в намей стране в целях безопасности не рекомендуется [9, 12].

Устойчивость материала к плесневому заражению повышает использование в технологическом цикле отделки тканей комбинированного процесса крашения и обработки растворами солей $\mathrm{MeCl} \times\left(\mathrm{Co}^{2+}, \mathrm{Ni}^{2+}\right.$, $\left.\mathrm{Cu}^{2+}, \mathrm{Ca}^{2+}, \mathrm{Al}^{3+}, \mathrm{Cr}^{3+}\right)$. Выкраски, обработанные растворами солей кобальта и никеля, становятся более устойчивыми к заражению тест-культур Aspergillus niger и Ulocladium atrum. Наблюдаемая закономерность обусловлена синергическим действием хелатообразующих групп красителя и солей [27].

Из металлов наиболее общепризнанным активным антисептиком является серебро. Препараты серебра чрезвычайно активно уничтожает бактерии. Оно в 1750 раз сильнее действия карболовой кислоты и в 3,5 раза сильнее действия сулемы. Всего 1мг/л серебра в течение 30 минут вызывал полную инактивацию вирусов гриппа $\mathrm{A}, \mathrm{B}$, Митре и Сендай (модификации вирусов парагриппа). По антибактериальным свойствам ни один антибиотик не может сравниться с действием серебра. Установлено, что любой из антибиотиков способен подавить не больше $5-6$ штаммов микробов, а эффективность ионов серебра в коллоидном растворе значительно сильнее проявляется по отношению к 500 штаммам и более [26, 28]. Микроорганизмы, подвергавшиеся воздействию антибиотиков, со временем мутируют, что нельзя сказать о серебре. Согласно таким характеристикам серебро выступает как препарат, обладающий высокими биоцидными свойствами. Серебро $\square$ металл, практически не изменяющийся под воздействием кислорода воздуха при комнатной температуре. Антибактериальное действие ионов серебра, наблюдающееся даже при концентрации $2 \cdot 10^{-11}$ г-ион/л, было открыто в 1893 году V. Naeqeli. [29]. В настоящее время известно, что при концентрации 0,1 мг/л серебро обладает выраженным фунгицидным действием. При микробной нагрузке 100000 клеток на один литр гибель грибов Candidaalbicans наступает через 30 минут после контакта с серебром [30].

Стабилизировать металлическое серебро в водной среде можно защитными коллоидами, например, водорастворимыми полимерами. Исследования показали, что чувствительность патогенных и непатогенных организмов неодинакова к воздействию ионов серебра. Патогенная микрофлора более восприимчива, чем непатогенная. Поэтому действие серебра является избирательным, в большей степени на более опасные микроорганизмы [31].

На основе наночастиц серебра в начале 2000$\mathrm{x}$ годов появилось новое поколение антисептиков 
- коллоидные растворы под маркой AgBion. Препараты AgБион-1 и АgБион-2 обладают бактерицидными, вирулентными, фунгицидными свойствами, а также активны по отношению к плесени и сине-зеленым водорослям. Препарат AgБион-2 в разбавленном виде может использоваться для дезинфекции помещений, предметов обстановки, оборудования в лечебнопрофилактических, пенитенциарных учреждениях, на объектах коммунального хозяйства [32]. АgБион-1 предназначен, главным образом, для модификации наночастицами серебра различных материалов. Введение наноразмерных частиц серебра в количестве от $0,01 \%$ до $0,1 \%$ от объема модифицируемого материала приводят к появлению стойкого биоцидного эффекта, однако этот npenapam выммывается водой [33].

Таким образом, анализ существующих в настоящее время биоцидных препаратов, показывает, что их применение для модификации текстильных хлопчатобумажных материалов бельевого ассортимента может быть ограничено по следующим причинам:

-нестойкость к влажно-тепловым обработкам: углеводороды, их галоген-и нитропроизводные, спирты, фенолы и их производные;

- токсичность в различной степени: пентахлорофен, элементорганические соединения ртути, олова, мышьяка, триклозан; растворы цитрата серебра, катамина АБ и лимонной кислоты;

-необходимость наличия специального оборудования при производстве азотсодержащих углеводородов;

- значительное окрашивание ткани: стеарат меди, нафтенат меди и 8-оксихинолят меди;

-ограниченный спектр антисептического действия: гексохлорофен и анилиновые красители (не воздействует на грамотрицательной бактерии), фурагин (не уничтожает синегнойную палочку), анимид салициловой кислоты и купроцин (являются только фунгицидами);

-угнетение работы иммунной системы: антибиотики.

Этих недостатков лишены препараты на основе наночастиц серебра. Их несомненными достоинствами являются:

- высокая антимикробная активность, в т. ч. способность подавлять наиболее адаптированные к внешним воздействиям микроорганизмы (или их видоизмененные формы);

- полный спектр антимикробного действия (бактерии, вирусы, грибы) и подавления патогенной микрофлоры (споры);

- отсутствие деструктирующего влияния на материалы обрабатываемых изделий;
- отсутствие в составе хлорсодержащих компонентов;

- экологическая безопасность [34].

К недостаткам практического применения наночастиц серебра можно отнести достаточно высокую стоимость и коричневатые оттенки модифицированных образцов, а также недостаточную прочность закрепления его в структуре ткани.

Серовато-коричневая модифицированных проб, обусловлена характерным избирательным поглощением светового излучения наноразмерными частицами серебра в области 406 нм $[13,19]$.

Однако на практике используют гидрозоли с достаточно низкой концентрацией серебра, что значительно снижает их стоимость. Кроме того, возможно изменение цветовой гаммы модифицированных образцов при сохранении бактерицидных свойств.

Решение проблемы недостаточной прочности закрепления наночастиц серебра в структуре ткани возможно путем осаждения защитных коллоидов полипептидой природы с образованием нерастворимых соединений на поверхности волокон. С этой целью можно применять экологически безопасные растительные дубители - танниды, которые содержатся в коре, древесине, листьях и плодах многих растений. Такие танниды как квебрахо $u$ мимоза используются при дублении кожи, танниды коры ели, каштана, дуба, акации - для придания различным напиткам терпкого и вяжущего вкуса и как пищевой краситель (Е 181). В медицине танниды коры дуба находят применение как вяжущие лекарственные кровоостанавливающие и общеукрепляющие средства. Они способны самостоятельно подавлять рост патогенных микроорганизмов. В воде танниды образуют коллоидные растворы, имеющие кислую реакцию и обладающие сильным дубильным действием, которое основано на способности взаимодействия отрицательно заряженных групп фенольного характера с положительно заряженными аминогруппами белка $[35,36]$.

Проведенный анализ выявил очевидные преимущества наночастиц серебра. Поэтому для модификации хлопчатобумажных тканей бельевого ассортимента были использованы гидрозоли серебра, созданные в ЗАО «ЦНТБ» [37]. При этом использовали два разных стабилизатора: сополимер акриловой кислоты с акриламидом и желатин. Содержание защитного коллоида в композициях составляло от 0,5 до 0,05 \% (масс.) Композиция, стабилизированная сополимером акриловой кислоты с акриламидом, проста в изготовлении, использовании и стабильна при хранении. Пищевой желатин в 


\begin{tabular}{|c|c|c|c|c|c|c|}
\hline Impact Factor: & $\begin{array}{l}\text { ISRA (India) } \\
\text { ISI (Dubai, UAF } \\
\text { GIF (Australia) } \\
\text { JIF }\end{array}$ & $\begin{array}{l}=1.344 \\
=0.829 \\
=0.564 \\
=1.500\end{array}$ & $\begin{array}{l}\text { SIS (USA) } \\
\text { PИНЦ (Russia) } \\
\text { ESJI (KZ) } \\
\text { SJIF (Morocco) }\end{array}$ & $\begin{array}{l}=0.912 \\
=0.234 \\
=3.860 \\
=\mathbf{2 . 0 3 1}\end{array}$ & $\begin{array}{l}\text { ICV (Poland) } \\
\text { PIF (India) } \\
\text { IBI (India) }\end{array}$ & $\begin{array}{l}=6.630 \\
=1.940 \\
=4.260\end{array}$ \\
\hline
\end{tabular}

качестве защитного коллоида применялся с целью повышения экологической безопасности системы и повышения её адсорбционной способности. Желатин, являясь полиамфолитом с большей молекулярной массой, чем сополимер акриловой кислоты с акриламидом, прочнее удерживает частицы серебра на поверхности волокон ткани.

Методика обработки тканей была зарегистрированный патентом РФ [38].

Образцы бязи обрабатывали композицией при различном содержании атомарного серебра 8 гидрозоле: от 0,0216 до $0,0018 \%$ (масс.). Уменьшение концентрации серебра в растворе проводили для снижения затрат и коррекции цвета образцов при сохранении антисептических свойств.

Для фиксации частиц серебра в структуре текстильного полотна применили два растительных дубителя: квебрахо $и$ мимозу. После обработки композициями на основе гидрозоля серебра проводили закрепление на одних образцах ткани в 1,5\%-ном растворе таннидов квебрахо и на других - в 1,5\%-ном растворе таннидов мимозы. После обработки в растворе квебрахо образцы приобретали более эстетичный светло - желтый тон, а мимоза предавала ткани персиковый оттенок.

Модифицированные образцы повергали пяти влажно-тепловым обработкам и последующему автоклавированию.

Для исследования антисептической устойчивости модифицированных образцов ткани были выбраны штаммы бактерий, чаще всего встречающиеся в транзитной микрофлоре: Bacilluc cereus sp. или Bacilluc licheniformis, Staphylococcus aureus и Escherichia coli.

Биоцидные свойства образцов были определены методом «зон», бактерицидные свойства - аэрозольным методом, а бактериостатические свойства устанавливали по высеву микроорганизмов на плотные питательные среды из растущей жидкой культуры.

Было установлено, что после первой стирки содержание серебра в образцах, как и антисептические свойства, несколько уменьшились, однако после второй и последующих стирок показатели стабилизировались: образцы сохраняли высокие бактерицидные и бактериостатические свойства.

\section{Conclusion}

Таким

образом, проведенное исследование показало высокую эффективность композиций, созданных на основе коллоидного серебра, а последующее применение таннидов, придало тканям эффект «невымываемости» с синергическим бактерицидным эффектом самих таннидов. В результате модифицированные материалы приобрели высокие потребительские антисептические свойства пролонгированного действия [39].

\section{References:}

1. Baranova ON, Mishakov VY, Zolina LI (2012) Classification of textile garments with antiseptic properties. // News of higher educational institutions. Technology of light industry. - Saint Petersburg: 2012. - №4. 103 108 p.

2. Rogovin ZA, Galbraikh LS (1979) Chemical transformations and modification of cellulose.

M.: Chemistry, 1979. - 205 p.

3. Pekhtasheva EL (2002) Biodeterioration and protection of non-food items. - M.: Skill. 2002. $220 \mathrm{p}$.

4. Krichevskii GE (2011) Nano-, bio-, chemical technology in manufacture of new generation of fibres, textiles and clothing. First edition. - M.: 2011. -528 p.
5. Galankin VN, Tokmakov AM (1991) Problems of inflammation from the standpoint of theory and practice. - Moscow: UDN. 1991. - $120 \mathrm{p}$

6. Rogovin ZA, Galbraikh LS (1979) Chemical transformations and modification of cellulose.

M.: Chemistry, 1979. - 205 p.

7. (1999) Device for energy effects. Pat. 2140796 Russian Federation, C1 6 A61N1/16, A61J1/10. No. 97113165/14; Appl. 1997.07.29; publ. 1999.11.10.

8. Sakharov EB (2012) an overview of the most important clinical studies on safety and influence of toothpaste containing a combination of triclosan/copolymer on the microflora of the oral cavity // Maestro dentistry. 2012. № 3(47). 57 - 60 p.

9. Egorova EM, Revina AA, Rostovshchikova TN, Kiselyova OI (2001) Bactericidal and 


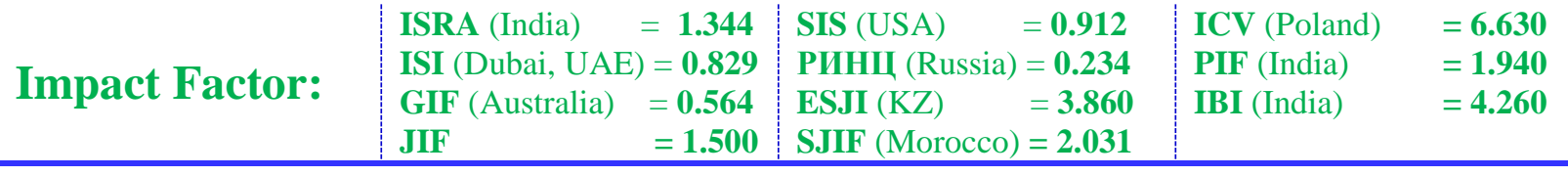

catalytic properties of stable metal nanoparticles in reverse micelles. // Vestnik MGU. ser.2. Chemistry, 2001. Vol. 42. No. 5. $332 \mathrm{p}$

10. Kozinda ZY, Gorbacheva EG, Suvorova LM (1988) Methods of obtaining textile materials with special properties (antimicrobial and flame retardant). - M.: Legprombytizdat, 1988. - 112 p.

11. Sedov AV, Goncharov SF, Onischenko GG, Tregub TI, Zhilyaev EG (1998) Antimicrobial materials in the prevention of infectious diseases. M. vtsmk "Protection". 1998. - 200 p.

12. Males AV, Barbinov VV, Litvishko AA (2014) Efficiency of modern means for individual prevention of pustular diseases of the skin. // Russian journal of skin and venereal diseases. 2014. T. 17. No. 1. $37-41$ p.

13. Koscheyev VS, Lamparska NN, Sedov AV, et al. (1987) Of Antimicrobial materials in medicine / ed. by ilina L. A. - M.: Medicine. 1987. - $192 \mathrm{p}$.

14. Wolf LA, Meos AI (1980) Fiber for special purposes. - M.: Chemistry. 1980. $-239 \mathrm{p}$

15. Lazarev NI, Levina EN (1976) Harmful substances in industry. A Handbook for chemists, engineers and doctors. Vol. 2. Organic matter 1976. $-624 \mathrm{p}$.

16. (1999) TU 9392 - 003 - 48482528 - 99 Catamin AB.

17. Gahanna TI, Osipov BP, et al. (2002) Domestic methods of control of environmental safety of products of textile and light industry. ROS.chem. the society they. D. I. Mendeleev, 2002. T. XLVI. - No. 2. 77-81 p.

18. Kuznetsov DN, Kobrakov KI, Dmitrieva MB, Toshkhodjaev NA (2016) The development of an algorithm for the synthesis of biocidal hetarylacetylenes and evaluation of their fungicidal properties // Bulletin of the PITT im. Acad. After M. Osimi. 2016. No. 1.120 - 126 p.

19. Karekin PP, Chubarova ZS, Afanasyeva RF (1982) Industrial design special clothes. - M: Light and food industry, 1982. $-280 \mathrm{p}$.

20. (1974) Cellulose and its derivatives [collection] / ed. by Bilza N. and Segal L.; lane. from English. ed. by Rogovina Z. A. - M.: Mir. - T. 2. $-510 \mathrm{p}$.

21. Melnikov BN, et al. (1982) Physical and chemical bases of process of the finishing production. - M: Light and food industry. 1982. $-184 \mathrm{p}$.

22. Vainberg VM, Stegena LM, Illarionova EL, Chufarovsky TI (2003) bioactive nonwovens / Technical textiles. - M.. No. 6. 24-26 p.

23. (2001) Disinfectant concentrate and method of its preparation, the Disinfectant and method of making / A. B. Arata; US Patent 6197814, MPKA 01 N 37/36 A 01 N 59/16, C 02 F 1/46,
059/00 A $01 \mathrm{~N}$ A $01 \mathrm{~N}$ 055/02, 037/04 A $01 \mathrm{~N}$

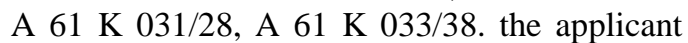
and правообладательNVID International, Inc. No. 09/169,229; Appl. 09.10.98; publ. 06.03.01.

24. (2011) Nanotechnology News Network, Nano Society 2011.

25. Velkhover ES (2004) Percutaneous diagnosis and therapy of trace elements. - M.: The "medicine". - $176 \mathrm{p}$.

26. Ivanov VN, Larionov GM, Kulish N, Lutzia MA (1995) Some experimental and clinical results of the use of silver cations in the fight against drug-resistant microorganisms. // Silver in medicine, biology and technology. Sib. otd.RAMS. 1995. No. 4. 53-62 p.

27. Safonov VV, Dmitrieva MB (2012) Comparative evaluation of fungicidal activity of some drugs on the textile materials during their restoration / Technology for the textile industry. 2012. Vol. 5, No. 341. 89 - 92 p.

28. Bryzgunov VS, Lapin VN, Matrosova VR (1964) Comparative evaluation of the bactericidal properties of silver water and antibiotics on pure cultures of microbes and their associations // Scientific. Tr. Kazan med. in-TA. 1964. T. 14. 121-122 p.

29. Abdalimov EV, Parsayev AA, Ershov BG (2011) preparation of nanoparticles of silver in the introductory solutions in the presence of ionizing carbonates. // - M.: Colloid journal. T. 73. № $1.3-8$ p.

30. Lidin RA, Molochko VA, Andreeva LL (2000) Chemical properties of inorganic substances. Chemistry. 286 p.

31. Doer R (1922) Zur Oligodinamie des Silbers / R. Doer, W/ Bergner // Biochem. Zeitschr. No. 131. 351-356 R.

32. (2006) TU $2499-003-44471019-2006$ Agbion - 2

33. (2006) TU $2499-002-44471019-2006$ Agbion -1

34. Bukin YA, Sergeeva EA (2012) Antibacterial properties and mechanism of bactericidal action of nanoparticles and silver ions // Bulletin of the Kazan technological University. No. 14, 2012. 170-172 p.

35. Sankov EA, Kalugin NB (1977) Microbiological damage of textile fibers. Leningrad: LTI. 1977. 85 p.

36. Zefirov NS, Kulov NN, et al. (1995) Chemical encyclopedia. - M.: Scientific publishing house "Great Russian encyclopedia". Vol. 4. 603p.

37. (2010) Composition based Hydrosol silver to give antimicrobial properties of fiber-mesh materials Pat. 2405557 Russian Federation, МПК7А 61 K 33/38, А 61 L 15/44. No. 2009121510/15; Appl. 08.06.09; publ. 10.12.10, bull. No. 34. p.5. 
\begin{tabular}{l|lrl|l|ll} 
& ISRA (India) & $=\mathbf{1 . 3 4 4}$ & SIS (USA) & $=\mathbf{0 . 9 1 2}$ & ICV (Poland) & $=\mathbf{6 . 6 3 0}$ \\
Impact Factor: & ISI (Dubai, UAE) $=\mathbf{0 . 8 2 9}$ & PUHL (Russia) $=\mathbf{0 . 2 3 4}$ & PIF (India) & $=\mathbf{1 . 9 4 0}$ \\
& GIF (Australia) & $\mathbf{0 . 5 6 4}$ & ESJI (KZ) & $=3.860$ & IBI (India) & $=\mathbf{4 . 2 6 0}$ \\
& JIF & $=\mathbf{1 . 5 0 0}$ & SJIF (Morocco) & $=\mathbf{2 . 0 3 1}$ & & \\
\hline
\end{tabular}

38. (2012) A method of producing a hydrophilic textile materials with antimicrobial properties. Pat. 2456995 Russian Federation, IPC AND 61K 33/38, A61L 15/46, A 01 N 59/00, 82 IN 3/00. No. 2011116905]. 28.04.11; publ. 27.07.12, bull. No. 21. P.4.
39. Baranova ON, Zolina LI, Mishakov VY (2016) Differential estimation method to the antiseptic properties of cotton fabrics linen range. Chemical fiber. No. 2. 63-67 p. 